\title{
Isotope and hydrochemistry reveal evolutionary processes of lake water in Qinghai Lake
}

\author{
Bu-Li Cui ${ }^{\text {a* }}, \quad$ Xiao-Yan Li ${ }^{\text {b }}, \quad$ Xing-Hua Wei ${ }^{a}$ \\ ${ }^{a}$ School of Resources and Environmental Engineering, Ludong University, Yantai 264025, China \\ ${ }^{b}$ State Key Laboratory of Earth Surface Processes and Resource Ecology, Beijing Normal University,
}

Beijing 100875, China

*Corresponding author:

Bu-Li Cui, School of Resources and Environmental Engineering, Ludong University, No. 186

Hongqizhong Street, Yantai, Shandong, 264025, China. Tel: +86-29-18049073788, Email:

cuibuli@163.com 
Abstract: Qinghai Lake is the largest lake in China, and is one of more than 500 brackish lakes on the Tibet Plateau. This study investigated stable isotopes $\left(\delta^{18} \mathrm{O}\right.$ and $\left.\delta^{2} \mathrm{H}\right)$ and hydrochemistry of lake water in Qinghai Lake and surrounding lakes to understand the lakes' evolutionary processes. These processes help explain the formation and evolution of the brackish and salt lakes on the Tibetan Plateau. The original isotopic and chemical compositions of lake water were controlled by a mixture of water from river water, groundwater and precipitation. The values of $\delta^{18} \mathrm{O}$ and $\delta^{2} \mathrm{H}$ of most of the lake water samples were greater than zero due to continuous strong evaporation. The cations were in the order: $\mathrm{Na}^{+}$ $>\mathrm{Mg}^{2+}>\mathrm{K}^{+}>\mathrm{Ca}^{2+}$, and anions were in the order: $\mathrm{Cl}^{-}>\mathrm{SO}_{4}{ }^{2-}>\mathrm{HCO}_{3}{ }^{-}$. The hydrochemical types of Qinghai Lake and surrounding lakes were $\mathrm{Na}^{+}-\mathrm{Cl}^{-}$. The lake water, excluding Erhai Lake, was saturated with $\mathrm{CaCO}_{3}$. There was significant aragonite precipitation, and the $\mathrm{Ca}^{2+}$ concentration was relatively low. Haiyanwan Lake and Gahai Lake, which have no surface water inputs, had experienced stronger evaporation than Qinghai Lake since the lakes were isolated from Qinghai Lake due to the dropping lake level and the arid climate. Erhai Lake water had relatively low salinity due to the fresh water coming in from the Daotang River. With the continued strong evaporation of lake water, Qinghai Lake and surrounding lakes should become increasingly saline. However, the salinity of lakes on the Tibetan Plateau is likely to slowly decrease in future decades due to the increasing precipitation and runoff, which will dilute lake water. In the longer term, however, Qinghai Lake and the brackish lakes will likely still become more saline, given the continued contribution of chemical ions from river water and groundwater and strong evaporation from the lake surface.

Keywords: Stable isotope; $\delta^{18} \mathrm{O}$ and $\delta^{2} \mathrm{H}$; hydrochemistry; lake water; Qinghai Lake 


\section{Introduction}

Qinghai Lake $\left(36^{\circ} 32^{\prime}-37^{\circ} 15^{\prime} \mathrm{N}, 99^{\circ} 36^{\prime}-100^{\circ} 47^{\prime} \mathrm{E}\right)$, China's largest lake, lies in the Northeast

Qinghai-Tibet Plateau, China (Fig. 1). The lake lies in a critical transitional zone (Fig. 1) where the Asian Summer Monsoon (ASM) and the Westerlies meet (LZBCAS, 1994). The hydrochemical processes and the evolution of Qinghai Lake are y sensitive to climate change (Sun et al., 1991; An et al., 2012), making Qinghai Lake an ideal site to study the competing influences of the humidity of the ASM and the aridity of the Westerlies on the northeastern Tibet Plateau (Li et al., 2007b; Liu et al., 2009; Henderson et al., 2010; Liu et al., 2011; An et al., 2012). Understanding the past dynamics of these two sub-systems will help predict possible impacts in this unique setting under the scenario of global warming.

Qinghai Lake is a brackish lake with a closed basin and no surface water outflows. It is one of China's national nature reserves and is an important water body influencing the ecological security of the Northeast Qinghai-Tibet Plateau (Tang et al., 1992). Over the past few decades, more than half of the rivers flowing into the Qinghai Lake have dried up, due to climate change and human activity (LZBCAS, 1994; Li et al., 2007a). This resulted in a drop in the lake's water level, from $3196.55 \mathrm{~m}$ in 1959 to $3194.08 \mathrm{~m}$ in 2012 (Li et al., 2007a; Li et al., 2012; Jin et al., 2013); as a result, the lake's surface area decreased and separate lakes were isolated from Qinghai Lake (e.g., Gahai Lake, Haiyanwan Lake, Erhai Lake) (Fig.1).

These hydrological processes have contributed to a series of environmental problems in the region, such as decreasing water supplies, water quality deterioration, desertification, and the loss of grazing grassland (Qin and Huang, 1998; Zhang et al., 2003; Hao, 2008). As a result, Qinghai Lake has emerged as an important research site, with many published studies investigating the hydrological processes of Qinghai Lake, such as lake level variation, water balance, evaporation, and the lake water's 
hydrochemistry (Qin and Huang, 1998; Yan and Jia, 2003; Li et al., 2005; Li et al., 2007a; Li et al., 2009;

Yi et al., 2010; Jin et al., 2010; Xu et al., 2010).

Very few studies, however, have investigated and analyzed the isotope and chemical characteristics of the precipitation, river water, and groundwater impacting the lake water of Qinghai Lake and surrounding lakes. As a whole, Qinghai Lake's evolution and the recharge relationships among the surrounding lakes are not fully understood. Further, Qinghai Lake is one of more than 500 brackish lakes on the Tibetan Plateau (Zheng, 1989; Jiang \& Huang, 2004; Ma et al., 2010; Song et al., 2014). As such, studying the isotope, hydrochemistry, and evolutionary process of Qinghai Lake water helps more broadly to explain the formation and evolution of the plateau's brackish and salt lakes under global warming conditions.

Therefore, this study used stable isotopes and hydrochemical information from water sources (lake water, river water, groundwater and precipitation) as tracers to: (1) investigate the spatial and temporal characteristics of stable isotopes and hydrochemistry of the lake waters in Qinghai Lake and surrounding lakes, (2) describe the evolution of the lake water, and (3) discuss possible future trends facing Qinghai Lake as a result of global warming. The results contribute to knowledge about the hydrological and geochemical evolutions of lakes in cold and arid alpine environments and also inform water resource management in the Qinghai Lake Basin and the northeastern Tibetan Plateau.

\section{Background of the Qinghai Lake}

Qinghai Lake has a water surface area of $4400 \mathrm{~km}^{2}$ and a water volume of $71.6 \times 10^{9} \mathrm{~m}^{3}$. It is the largest lake in China, and lies in the cold and semiarid region of the northeastern Tibetan Plateau at an altitude of $\sim 3,193 \mathrm{~m}$ above sea level (Fig. 1). The lake is a closed basin with a watershed area of approximately $29,661 \mathrm{~km}^{2}$, with no surface water outflows. The average annual air temperature in the 
lake area is $\sim-0.1{ }^{\circ} \mathrm{C}$. The average annual precipitation is $\sim 357 \mathrm{~mm}$, with more than $65 \%$ falling as rain in summer. The evaporation rate is 3-4 times higher than the precipitation rate ( $\mathrm{Li}$ et al., 2007a). The climate of Qinghai Lake is influenced by two air masses: the Asian Summer Monsoon (ASM) and the Westerlies. The ASM reaches the region in summer, while the Westerlies dominate in winter, resulting in a clear seasonality in precipitation (An et al., 2012; Cui \& Li, 2015b).

The lake water has a salinity of $15.5 \mathrm{~g} / \mathrm{L}$ and $\mathrm{pH}$ of 9.06 . Its water chemistry is characterized as $\mathrm{Na}^{+}>$ $\mathrm{Mg}^{2+}>\mathrm{K}^{+}>\mathrm{Ca}^{2+}$ and $\mathrm{Cl}^{-}>\mathrm{SO}_{4}{ }^{2-} \approx \mathrm{HCO}_{3}{ }^{2-}>\mathrm{NO}_{3}{ }^{-}$(Sun et al., 1991). This composition is similar to other saline lakes on the Tibetan Plateau (Zheng, 1989). Due to drops in the lake's water level, new lakes have formed as a result of isolation from Qinghai Lake. For example, Haiyanwan Lake formed in 1987; Erhai Lake formed more than 100 years ago; and Gahai Lake formed into its current shape around the early Holocene (Shi et al., 1958; Chen et al., 1990; LZBCAS, 1994). More than 50 rivers or streams flow into Qinghai Lake (LZBCAS, 1994). The rivers are asymmetrically distributed, with most located north and northwest of the lake (Fig. 1; Yan \& Jia, 2003). Most rivers are seasonal, with $85 \%$ of the annual discharge occurring between June and September. The main rivers are Buha River, Shaliu River, Haergai River, Quanji River, and Heima River (LZBCAS, 1994; Li et al., 2007a). Together, these 5 rivers have a total discharge of $1.43 \times 10^{9} \mathrm{~m}^{3} / \mathrm{yr}$ which constitutes $80.3 \%$ of the total surface water volume flowing into Qinghai Lake. The groundwater table around Qinghai Lake usually varies between 4 - $7 \mathrm{~m}$ below ground surface (Cui \& Li, 2014). Mountain runoff to the alluvial and diluvial plains recharges the groundwater via infiltration. Groundwater discharge largely occurs in the lacustrine plain surrounding the lake.

\section{Sampling and methods}

Lake water samples were collected monthly from July 2009 to June 2010 at 8 locations. Of these, 5

sampling sites (L1-L5) were in Qinghai Lake and 3 sampling sites were in Haiyanwan Lake, Gahai Lake, 
and Erhai Lake (Fig.1). A total of 68 lake water samples were collected. All samples were clean water collected into bottles hand-dipped approximately $0.2 \mathrm{~m}$ below the water surface and 5-10 $\mathrm{m}$ from the lake bank. Additionally, 6 samples of lake water (Fig.1) were collected from the center of Qinghai Lake in November 2009, supplementing the samples from sites L1-L5 which were closer to shore.

All samples were filtered through $0.45 \mu \mathrm{m}$ nylon filters. Water samples were stored in $100 \mathrm{ml}$ high-density polyethylene square bottles for isotopic analyses and $500 \mathrm{ml}$ bottles for chemical analyses. Samples for cation testing were acidified with ultrapure $\mathrm{HCl}$. The samples for anion and isotope testing were transported with ice bags and then refrigerated at approximately $4{ }^{\circ} \mathrm{C}$ until laboratory analysis. The electrical conductivity (EC) of the river water was measured in situ using a handheld meter with a probe. Precipitation, river water and groundwater samples around Qinghai Lake were collected monthly in the same period (Fig.1).

Isotopic values were expressed using delta notation $(\delta)$ relative to the Vienna Standard Mean Ocean Water (V-SMOW standard). The samples' stable isotopic compositions were analyzed using the Picarro L1102-i water isotope analyzer at the Stable Isotope Laboratory, Institute of Geology and Geophysics, Chinese Academy of Sciences. The precision was $\pm 0.5 \%$ and $\pm 0.1 \%$ for $\delta^{2} \mathrm{H}$ and $\delta^{18} \mathrm{O}$, respectively. The samples' chemical analyses were performed at the Analytical Laboratory, Beijing Research Institute of Uranium Geology. Major cations were determined using a Dionex-600 ion chromatograph; anions were measured using a Dionex-500 ion chromatograph.

\section{Results and discussion}

\section{Stable isotope in lake waters}

The average values of $\delta^{18} \mathrm{O}$ and $\delta^{2} \mathrm{H}$ in the lake water samples, collected from sites L1-L5 in

November 2009, were $1.61 \%$ and $7.71 \%$, respectively. The average values of the 6 lake water samples, 
collected at the center of Qinghai Lake in November 2009, were 1.59\%o and 7.62\%, respectively. These results indicate that the stable isotope values near the shore (L1-L5) were similar to those at the lake's center, and that the near-shore samples represented the isotopic and hydrochemical characteristics of Qinghai Lake water overall.

The $\delta^{18} \mathrm{O}$ and $\delta^{2} \mathrm{H}$ values of Qinghai Lake water, collected monthly from July 2009 to June 2010 (L1-L5), ranged from $-0.92 \%$ to $2.29 \%$ and from $-7.73 \%$ to $11.39 \%$, respectively (Fig. 2). The average $\delta^{18} \mathrm{O}$ value was $1.28 \%$ and the average $\delta^{2} \mathrm{H}$ value was $5.63 \%$ across the monthly samples (Table 1 ). The $\delta^{18} \mathrm{O}$ and $\delta^{2} \mathrm{H}$ signatures of most samples were positive, with the lowest $\delta^{18} \mathrm{O}$ and $\delta^{2} \mathrm{H}$ values observed near river estuaries (e.g. sample L2 and L5; Table 1).

Compared with Qinghai Lake water, the stable isotope values of Haiyanwan Lake were relatively higher $\left(\delta^{18} \mathrm{O}\right.$ and $\delta^{2} \mathrm{H}: 2.92 \%$ and $13.10 \%$, respectively), while the values of Gahai Lake water $\left(\delta^{18} \mathrm{O}\right.$ and $\delta^{2} \mathrm{H}: 0.84 \%$ and $-4.40 \%$, respectively) and Erhai Lake water $\left(\delta^{18} \mathrm{O}\right.$ and $\delta^{2} \mathrm{H}: 0.14 \%$ and $-8.13 \%$, respectively) were lower (Table 1; Fig. 2). These higher isotope values suggests that Haiyanwan Lake water has experienced stronger evaporation than Qinghai Lake water (Clark \& Fritz, 1997). Daotang River water was the sole surface river source flowing into Erhai Lake (Cui \& Li, 2015a); the river had relatively low $\delta^{18} \mathrm{O}$ and $\delta^{2} \mathrm{H}$ values (-3.90\%o and $-32.58 \%$, respectively), which helped explain the lower isotope values in Erhai Lake water (Fig. 2). For Gahai Lake, because there was no incoming surface water (Fig. 1) and a high evaporation rate, the stable isotope values should be higher than Qinghai Lake water (Clark \& Fritz, 1997). However, Gahai Lake water's stable isotopes were unexpectedly lower than Qinghai Lake water (Table 1). This would be because Gahai Lake was fed by relatively depleted groundwater.

When investigating regional hydrology, comparing the local evaporation lines (LEL) of water bodies with the local meteoric water line (LMWL) was useful for determining the water source (Clark \& Fritz, 
1997). Figure 2 and Table 2 showed that all of the isotopic data for both river water and groundwater were close to the LMWL. The stable isotope values in lake water were higher than values in precipitation, river water, and groundwater (Fig. 2). The LEL slopes of river water and groundwater (5.70 and 6.63, respectively) were smaller than the LMWL slope (7.86). These all suggested that the river water and groundwater mainly come from basin precipitation that had undergone weak evaporation (Paul \& Wanielista, 2000; Cui \& Li, 2014; Cui \& Li, 2015a).

The Qinghai Lake's LEL slope (5.67) and Haiyanwan Lake's LEL slope (5.29) were similar to the river water's LEL slope (5.70). Both lakes' LEL slopes were smaller than the groundwater's LEL slope (6.63) and LMWL slope (7.86) in the Qinghai Lake Basin (Fig. 2; Table 2). The $\delta^{18} \mathrm{O}$ and $\delta^{2} \mathrm{H}$ values at the intersection between the Qinghai Lake's LEL and the LMWL were $-7.59 \%$ and $-44.65 \%$, respectively. These values were within the ranges of precipitation $\left(\delta^{18} \mathrm{O}:-24.40\right.$ to $-2.80 \%, \delta^{2} \mathrm{H}:-180.80$ to $-11.54 \%$; Cui \& $\mathrm{Li}, 2015 \mathrm{~b})$, river water $\left(\delta^{18} \mathrm{O}:-9.78 \%\right.$ to $-3.9 \%$, $\delta^{2} \mathrm{H}:-63.62 \%$ to $-32.58 \%$; $\mathrm{Cui} \& \mathrm{Li}$, 2015a) and groundwater ( $\delta^{18} \mathrm{O}:-10.20 \%$ to $-6.45 \%, \delta^{2} \mathrm{H}:-66.79 \%$ to $-39.61 \%$; $\left.\mathrm{Cui} \& \mathrm{Li}, 2014\right)$ in the Qinghai Lake Basin. Qinghai Lake is a closed basin with no surface water outflow. All of these results suggested that lake water coming from the precipitation, river water, and groundwater in the basin, and the lake water had undergone high evaporation (Friedman et al. 1962; Paul and Wanielista 2000). Haiyanwan Lake's LEL slope (5.29) was smaller than Qinghai Lake's LEL slope (5.67). Further, $\delta^{18} \mathrm{O}$ and $\delta^{2} \mathrm{H}$ were higher in Haiyanwan Lake than Qinghai Lake.

The average $\delta^{18} \mathrm{O}$ and $\delta^{2} \mathrm{H}$ values of Qinghai Lake water fluctuated slightly within the year (Fig. 3). The isotopic values dropped gradually from February to July and increased gradually from July through February (lower values in summer and higher values in winter) (Fig. 3). The low isotope values in July and August were closely related to high precipitation and high river runoff supplying Qinghai Lake in the summer (more than $65 \%$ precipitation and $85 \%$ of the annual discharge of river occur in summer 
season). Precipitation and river water had relatively lower stable isotope values than lake water (Fig. 2).

Inversely, low precipitation and river runoff occurred in the dry season (between November and April);

the higher isotope value of lake water was closely related to the high evaporation.

\section{Hydrochemistry of lake waters}

The total dissolved solids (TDS) and electrical conductivity (EC) values of Qinghai Lake water ranged from $14.2 \mathrm{~g} / \mathrm{L}$ to $16.1 \mathrm{~g} / \mathrm{L}$ and from $15.6 \mathrm{mS} / \mathrm{cm}$ to $18.1 \mathrm{mS} / \mathrm{cm}$ (Table 1 ), respectively. The average TDS was $15.1 \mathrm{~g} / \mathrm{L}$ and the average EC was $16.5 \mathrm{mS} / \mathrm{cm}$. The TDS of Qinghai Lake water was higher than the TDS of precipitation (0.07 g/L; Hou et al., 2009), river water (0.34 g/L; Cui \& Li, 2015a), and groundwater $(0.54 \mathrm{~g} / \mathrm{L}$; Cui \& Li, 2014) around Qinghai Lake. The cation concentrations of Qinghai Lake water were in the order: $\mathrm{Na}^{+}>\mathrm{Mg}^{2+}>\mathrm{K}^{+}>\mathrm{Ca}^{2+}$, and anions were in the order: $\mathrm{Cl}^{-}>\mathrm{SO}_{4}{ }^{2-}>\mathrm{HCO}_{3}{ }^{-}$

(Table 1). The $\mathrm{Ca}^{2+}$ concentration was very low (approximately $0.3 \mathrm{mmol} / \mathrm{L}$ ) in Qinghai Lake water, due to $\mathrm{CaCO}_{3}$ saturation and aragonite precipitation (Sun et al., 2002). Table 1 and Figure 1 showed that lake water TDS and EC were relatively low in the west and north part of Qinghai Lake; conversely, TDS and EC were relatively high in the southeast part. This would be because the rivers are asymmetrically distributed in the basin, with most of them located at north and northwest of the lake (Fig. 1). As such, the lake water's TDS and EC were diluted by fresh river water in the west and north part of Qinghai Lake, but not in the southeast part.

Table 1 presented the hydrochemistry of lake water in surrounding lakes. The TDS and EC of Haiyanwan Lake water were $24.2 \mathrm{~g} / \mathrm{L}$ and $25.1 \mathrm{mS} / \mathrm{cm}$, respectively; and the TDS and EC of Gahai Lake water were $32.6 \mathrm{~g} / \mathrm{L}$ and $48.6 \mathrm{mS} / \mathrm{cm}$, respectively. Major ion concentrations, TDS, and EC in Haiyanwan Lake and Gahai Lake waters were all much higher than that in Qinghai Lake water (Table 1). These indicated that Haiyanwan Lake and Gahai Lake waters had undergone strong evaporation, because drops in lake level isolated these water bodies from Qinghai Lake. High $\mathrm{Ca}^{2+}$ concentration in Gahai 
Lake water suggested that this lake could be fed by fresh groundwater. The TDS and EC of Erhai Lake water $(1.01 \mathrm{~g} / \mathrm{L}$ and $1.2 \mathrm{mS} / \mathrm{cm}$, respectively) were much lower than that of Qinghai Lake and other surrounding lakes (Table 1). Erhai Lake receives inflow from theDaotang River, with relatively low TDS and EC (Cui \& Li, 2015a).

Based on the ternary diagrams in Figure 4, the hydrochemical type of lake water in Qinghai Lake and surrounding lakes was $\mathrm{Na}^{+}-\mathrm{Cl}^{-}$. The boomerang envelope model, developed by Gibbs (1970), describes and classifies natural water chemistry controls into three types: precipitation dominance, rock dominance, and evaporation/crystallization dominance (Machender et al., 2014). As shown in Figure 5, Qinghai Lake, Haiyanwan Lake, and Gahai Lake water all mapped to the right upper part of the Gibbs boomerang envelope, meaning with very high TDS and high $\mathrm{Na}^{+} /\left(\mathrm{Na}^{+}+\mathrm{Ca}^{2+}\right)$ and high $\mathrm{Cl}-\left(\mathrm{Cl}^{-}+\mathrm{HCO}_{3}^{-}\right)$ ratios, similar to the ocean waters. The Erhai Lake water fell within the evolutionary path from "Rock dominance" to "Ocean" in the Gibbs boomerang envelope. All of these results again highlighted strong evaporation in Qinghai Lake and surrounding lakes, leading to relatively high ion concentrations, despite the lower ion levels in the incoming river water and groundwater. The strong lake water evaporation and the salt crystallization are likely the main processes explaining the lakes hydrochemistry (Sun et al., 2002; Xu et al., 2010).

\section{Evolution of Qinghai Lake and surrounding lakes}

According to the Table 3, TDS was highest in Gahai Lake, followed by Haiyanwan Lake, Qinghai Lake, and finally Erhai Lake. For each lake, TDS and most ion concentrations increased from 1961 to 2009 (Table 3). It has been reported that aragonite tends to precipitate when the $\mathrm{Mg} / \mathrm{Ca}$ ratio exceeds 12:1 (Jones \& Deocampo, 2003). Table 3 showed that the $\mathrm{Mg} / \mathrm{Ca}$ ratios in Qinghai Lake and surrounding lakes, excluding Erhai Lake, generally exceeded 90:1. Consequently our results indicated that the lakes, excluding Erhai Lake, were saturated by $\mathrm{CaCO}_{3}$ and were precipitating aragonite (Table 3; Fig. 6). 
The TDS of Qinghai Lake water was inversely related to lake level (Table 3 and Fig. 6); TDS peaks corresponded to relatively low lake levels while TDS declines corresponded to relatively high lake levels (Fig. 7). Pearson correlation coefficients showed that TDS variation was negatively correlated to lake level, at a significance level of $\mathrm{p}<0.001$ (Fig. 8). The regression equation indicated that a lake level change of $1 \mathrm{~m}$ would result in a TDS change of $1.01 \mathrm{~g} / \mathrm{L}$ (Fig. 8). Lake level increases are closely related to a wet climate and high runoff while lake level decreases are closely related to dry climate and low runoff (Cui \& Li, 2015a). These results indicated that, when high precipitation and high runoff increase lake level, then the ion concentration in lake water decreases. In contrast, strong lake water evaporation decreased lake level, increasing ion concentrations and crystallization (precipitation) of salt and other minerals such as aragonite and hydromagnesite (Table 3; Fig. 7; Xu et al., 2010).

In considering the evolution of Qinghai Lake over time, it was likely that the original chemical composition of Qinghai Lake was controlled by a mixture of river water, groundwater, and precipitation around the lake. Chemical ions, dissolved in river water and groundwater, would have been continually carried into the lake. After their separation from Qinghai, Haiyanwan Lake and Gahai Lake had undergone relatively much stronger evaporation than Qinghai Lake because of their isolation from Qinghai Lake, a lack of incoming surface water, and the arid climate. The presence of hydromagnesite in Haiyanwan Lake and Gahai Lake showed that Qinghai Lake has become increasingly saline (Sun et al., 1995; Sun et al., 2009; Xu et al., 2010). Erhai Lake water, on the other hand, had relatively low salinity because of the incoming fresh water from Daotang River. Erhai Lake's stable isotope and hydrochemistry would become more like Qinghai Lake, if the incoming water from Daotang River decreased. Similarly, the stable isotope and hydrochemistry of Qinghai Lake would become more like Haiyanwan Lake or Gahai Lake water (Sun et al., 1991; LZBCAS, 1994), if the incoming surface runoff and groundwater decreased. 


\section{Conclusions}

The lake water in Qinghai Lake and surrounding lakes came primarily from basin precipitation, river water, and groundwater, and had undergone high evaporative concentration. The hydrochemical types of Qinghai Lake and surrounding lakes were $\mathrm{Na}^{+}-\mathrm{Cl}^{-}$. The strong lake water evaporation and the salt crystallization from the lake water should be driving factors contributing to the lake water's stable isotopes and hydrochemistry. Qinghai Lake's stable isotope and hydrochemistry would evolve towards the levels found in Haiyanwan Lake or Gahai Lake water, if the incoming water from surface and ground runoff decreased. Erhai Lake water had relatively low salinity level, due to incoming fresh water from Daotang River. If that incoming water decreased, Erhai Lake's stable isotope and hydrochemistry might evolve towards the levels seen with Qinghai Lake water.

It is predicted that in future decades, lake levels may rise due to the combined effects of changing rainfall patterns, increased grass vegetation, and thawing permafrost as a result of global warming on the Tibetan Plateau (Christensen et al., 2014; Song et al., 2014; Yang et al., 2014; Cui \& Li, 2015b). This would decrease brackish lake's salinity on the Tibetan Plateau, due to freshwater dilution. However, over a longer time scale if the brackish lakes remain closed (e.g., Qinghai Lake, Haiyanwan Lake, Gahai Lake), they will become more saline due to the continuous influx of chemical ions from river water and groundwater, and the impacts of dry climate causing strong lake water evaporation.

\section{Acknowledgements}

The study was supported by the National Science Foundation of China (NSFC41130640,

NSFC41201039); the Fundamental Research Funds for the Central Universities, PCSIRT (No.IRT1108); and the State Key Laboratory of Earth Surface Processes and Resource Ecology.

\section{References}


An, Z.S., Colman, S.M., Zhou, W.J., Li, X.Q., Brown, E.T., Jull, A.J.T., Cai, Y.J., Huang, Y.S., Lu, X.F., Chang, H., Song, Y.G., Sun, Y.B., Xu, H., Liu, W.G., Jin, Z.D., Liu, X.D., Cheng, P., Liu, Y., Ai, L., Li, X.Z., Liu, X.J., Yan, L.B., Shi, Z.G., Wang, X.L., Wu, F., Qiang, X.K., Dong, J.B., Lu, F.Y., Xu, X.W., 2012. Interplay between the Westerlies and Asian monsoon recorded in Lake Qinghai sediments since 32 ka. Scientific Reports, 2, 619; DOI:10.1038/srep00619.

Chen, K.Z., Bowler, J.M., Kelts, K., 1990. Palaeoclimatic evolutions within the Qinghai-Xizang (Tibet) Plateau in the last 40000 years. Quaternary Sciences, (1): 21-31 (in Chinese).

Christensen, J.H., Kumar, K.K., Aldrian, E., 2014. Climate phenomena and their relevance for future regional climate change. Climate Change 2013: The Physical Science Basis. Working Group I Contribution to the Fifth Assessment Report of the Intergovernmental Panel on Climate Change, eds Stocker TF, et al. (Cambridge University Press, Cambridge, UK).

Clark, I.D., Fritz, P., 1997. Environmental isotopes in hydrogeology. New York: Lewis Publishers.

Cui, B.L., Li, X.Y., 2014. Characteristics of stable isotope and hydrochemistry of the groundwater around Qinghai Lake, NE Qinghai-Tibet Plateau, China. Environmental Earth Sciences, 71:1159-1167.

Cui, B.L., Li, X.Y., 2015a. Runoff processes in the Qinghai Lake Basin, Northeast Qinghai-Tibet Plateau, China: Insights from stable isotope and hydrochemistry. Quaternary International, 380-381: 122-132.

Cui, B.L., Li, X.Y., 2015b. Stable isotope reveal sources of precipitation in the Qinghai Lake Basin of the northeastern Tibetan Plateau. Science of the Total Environment, 527-528: 26-37.

Friedman, I., Machta, L., Soller, R., 1962. Water vapour exchange between a water droplet and its environment. Journal of Geophysical Research, 67: 2761-2766.

Gibbs, R.J., 1970. Mechanisms controlling world water chemistry. Science, 170:1088-1090.

Hao, X., 2008. A green fervor sweeps the Qinghai-Tibetan Plateau. Science, 321: 633-635.

Henderson, A.C.G., Holmes, J.A., Leng, M.J., 2010. Late Holocene isotope hydrology of Lake Qinghai, NE Tibetan Plateau: effective moisture variability and atmospheric circulation changes. Quaternary Science Reviews, 29: 2215-2223.

Hou, Z.H., Xu, H., An, Z.S., 2009. Major ion chemistry of waters in Lake Qinghai Catchment and the possible controls. Earth and Environment, 37(1): 11-19.

Jiang, J.H., Huang, Q., 2004. Distribution and variation of lakes in Tibetan Plateau and their comparison 
with lakes in other part of China. Water Resources Protection, 6: 24-27 (in Chinese).

Jin, Z.D., Wang, S.M., Zhang, F., Shi, Y.W., 2010. Weathering, Sr fluxes, and controls on water chemistry in the Lake Qinghai catchment, NE Tibetan Plateau. Earth Surface Processes and Landforms, 35: 1057-1070.

Jin, Z.D., Zhang, F., Wang, H.L., Bai, A.J., Qiu, X.N., 2013. The reasons of rising water level in Lake Qinghai since 2005. Journal of Earth Environment, 4(3): 1355-1362 (in Chinese).

Jones, B.F., Deocampo, D.M., 2003. Geochemistry of Saline Lakes. In: Treatise on Geochemistry, vol. 5, ISBN 0-08-043751-6, pp. 393-424.

Li, L., Zhu, X.D., Wang, Z.Y., Wang, Q.C., 2005. Impacting Factors and Changing Tendency of Water Level in Qinghai Lake in Recent 42 Years. Journal of Desert Research, 25(5): 689-696 (in Chinese).

Li, X.D., Xiao, J.S., Li, F.X., Xiao, R.X., Xu, W.X., Wang, L., 2012. Remote sensing monitoring of the Qinghai Lake based on EOS /MODIS data in recent 10 years. Journal of Natural Resources, 27(11): 1962-1970 (in Chinese).

Li, X.Y., Ma, Y.J., Xu, H.Y., Wang, J.H., Zhang, D.S., 2009. Impact of land use and land cover change on environmental degradation in Lake Qinghai watershed, northeast Qinghai-Tibet Plateau. Land Degradation \& Development, 20: 69-83.

Li, X.Y., Xu, H.Y., Sun, Y.L., Zhang D.S., Yang, Z.P., 2007. Lake-level change and water balance analysis at Lake Qinghai, west China during recent decades. Water Resources Management, 21: $1505-1516$.

Li, X.Z., Liu, W.G., Zhang, P.X., An, Z.S., Zhang, L., 2007b. Species, valve size, and pretreatment effects on $\delta 18 \mathrm{O}$ and $\delta 13 \mathrm{C}$ values of ostracod valves from Lake Qinghai, Qinghai-Tibet Plateau. Chemical Geology, 246: 124-134.

LIGCAS (Lanzhou Institute of Geology, Chinese Academy of Sciences), 1979. Comprehensive investigation report of Qinghai Lake. Science Press, Beijing (in Chinese).

Liu, W.G., Li, X.Z., Zhang, L., An, Z.S., Xu, L.M., 2009. Evaluation of oxygen isotopes in carbonate as an indicator of lake evolution in arid areas: The modern Qinghai Lake, Qinghai-Tibet Plateau. Chemical Geology, 268: 126-136.

Liu, X.J., Lai, Z.P., Yu, L.P., Liu, K., Zhang, J.R., 2011. Lake level variations of Qinghai Lake in northeastern Qinghai-Tibetan Plateau since 3.7 ka based on OSL dating. Quaternary International, 236: 57-64. 
LZBCAS (Lanzhou Branch of Chinese Academy of Sciences), 1994. Evolution of recent environment in Qinghai Lake and its prediction. Science Press, Beijing (in Chinese).

Ma, R., Duan, H., Hu, C., Feng, X., Li, A., Ju, W., Jiang, J., Yang, G., 2010. A half-century of changes in China's lakes: Global warming or human influence?, Geophysical Research Letters, 37, L24106, doi:10.1029/2010GL045514.

Machender, G., Dhakate, R., Reddy, M.N., Reddy, I.P., 2014. Hydrogeochemical characteristics of surface water (SW) and groundwater (GW) of the Chinnaeru River basin, northern part of Nalgonda District, Andhra Pradesh, India. Environmental Earth Sciences, 71: 2885-2910.

Paul, G., Wanielista, M., 2000. Effects of evaporative enrichment on the stable isotope hydrology of a central Florida (USA) river. Hydrological Processes, 14: 1465-1484.

Qin, B.Q., Huang, Q., 1998. Evaluation of the climatic change impacts on the inland lake-a case study of lake Qinhai, China. Climatic Change, 39: 695-714.

Shi, Y.F., Chen, L.X., Li, W.Z., Yi, S.M., 1958. The preliminary investigation of natural geography (Geomorphology) around Qinghai Lake. Acta Geographica Sinica, 24(1): 33-48.

Song, C., Huang, B., Richards, K., Ke, L., Phan, V.H., 2014. Accelerated lake expansion on the Tibetan Plateau in the 2000s: Induced by glacial melting or other processes?. Water Resources Research, 50, doi:10.1002/2013WR014724.

Song, C.Q., Huang, B., Ke, L.H., Richards, K.S., 2014a. Seasonal and abrupt changes in the water level of closed lakes on the Tibetan Plateau and implications for climate impacts. Journal of Hydrology, 514: 131-144. 10.1016/j.jhydrol.2014.04.018

Sun, D.P., 1995. An investigation on evaporating experiments for Qinghai Lake water, China. Journal of Salt Lake Science, 3(2): 10-19.

Sun, D.P., Li, B.X., Ma, Y.H., Liu, Q.Z., 2002. An investigation on evaporating experiments for Qinghai Lake water, China. Journal of Salt Lake Research, 10(4): 1-12.

Sun, D.P., Tang, Y., Xu, Z.Q., Han, Z., 1991. A preliminary investigation on chemical evolution of the Lake Qinghai water. Chinese Science Bulletin, 15: 1172-1174 (in Chinese).

Tang, R.C., Gao, X.Q., Zhang, J., 1992. The annual changes of the water level of the Lake Qinghai in the recent thirty years. Chinese Science Bulletin, 37(6): 524-524 (in Chinese).

Xu, H., Hou, Z., An, Z., Liu, X., Dong, J., 2010. Major ion chemistry of waters in Lake Qinghai catchments, NE Qinghai-Tibet plateau, China. Quaternary International, 212: 35-43. 
Yan, H.Y., Jia, S.F., 2003. Water balance and water resources allocation of Qinghai Lake. Journal of Lake Science, 15(1): 35-40 (in Chinese).

Yang, B., Qin, C., Wang, J.L., He, M.H., Melvin, T.M., Osborn, T.J., Briffa, K.R., 2014. A 3,500-year tree-ring record of annual precipitation on the northeastern Tibetan Plateau. PNAS, 111(8): 2903-2908.

Yi, W.J., Li, X.Y., Cui, B.L., Ma, Y.J., 2010. Climate change and impact on water level of the Qinghai Lake Watershed. Journal of Arid Meteorology, 28(4): 375-383 (in Chinese).

Yu, J.Q., Kelts, K.R., 2002. Abrupt changes in climatic conditions across the Lateglacial/Holocene transition on the N.E. Tibet-Qinghai Plateau: evidence from Lake Qinghai, China. Journal of Paleolimnology, 28: 195-206.

Zhang, D.S., Wu, J.W., Lu, R.J., Zhao, Y.Z., Chen, Y., 2003. Study on planning of the synthetic control of land desertification in the peripheral area of the Qinghai Lake. Arid Zone Research, 20(4): 307-311 (in Chinese).

Zheng, M.P., 1989. Saline Lakes on the Qinghai-Xizang (Tibet) Plateau. Science \& Technology Publishing House: Beijing; 210 (in Chinese). 


\section{List of Figures}

Fig. 1. Location of the Qinghai Lake Basin, its sub-catchments, and water sampling sites

Fig. 2. Stable isotopes of lake water, precipitation, river water, and groundwater in the Qinghai Lake Basin with local meteoric water line (LMWL) and local eaporation lines (LEL) for river water, groundwater, and lake water in the Qinghai Lake Basin. Lines for differerent lakes indicated by first letter of lake name

Fig. 3. Monthly values for stable isotopes (A) and d-excess and TDS (B) of Qinghai Lake water. Fig. 4. Ternary plots of cations and anions of lake water, precipitation, river water, and groundwater in the Qinghai Lake Basin with arrows indicating likely evolution of ionic composition.

Fig. 5. Plots of the major cation ratios (left panel) and major anion ratios (right panel) within the Gibbs boomerang model (outlined in dashed lines) indicating dominant processes for formation of lake water, river water, and groundwater in the Qinghai Lake Basin.

Fig. 6. Percentages of the major cations (A) and the major anions (B) in Qinghai Lake for years sampled from 1961 to 2009. Annual lake levels connected by solid line. Fig. 7. TDS and lake level changes in Qinghai Lake from 1961 to 2009.

Fig. 8. Relationship between Qinghai Lake TDS and water level.

Table captions:

Table 1. Stable isotopes and hydrochemical composition of lake water, river water, and groundwater in sampled water sources of Qinghai basin. Sample site locations given in Figure 1.

Table 2. Local meteoric water line (LMWL) and Evaporation lines (LEL) of river water, ground water, and lake water in the Qinghai Lake Basin.

Table 3. Changes of hydrochemical composition of lake water in Qinghai Lake and surrounding lakes 
from 1961 to 2009. 


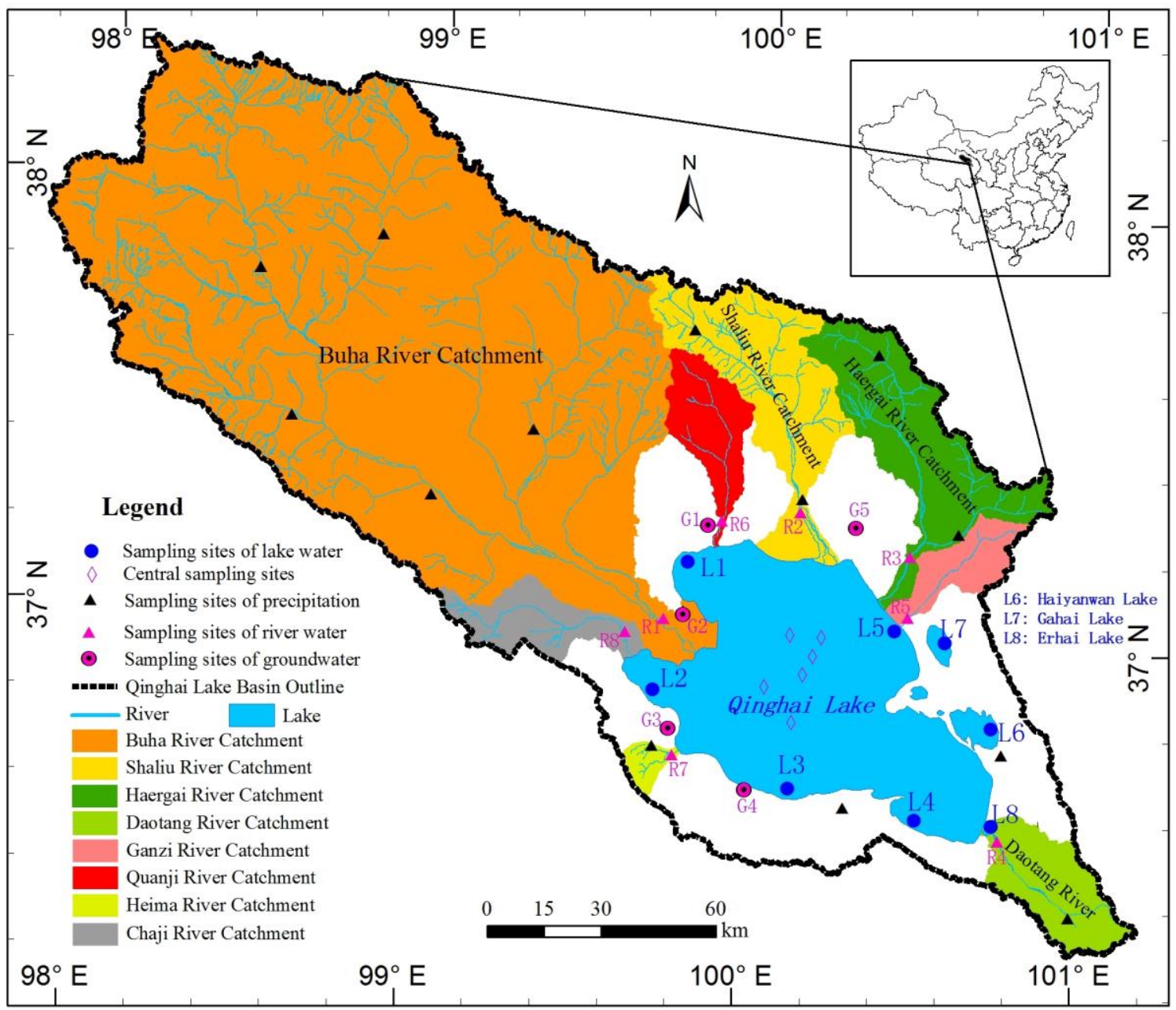

Figure 1 


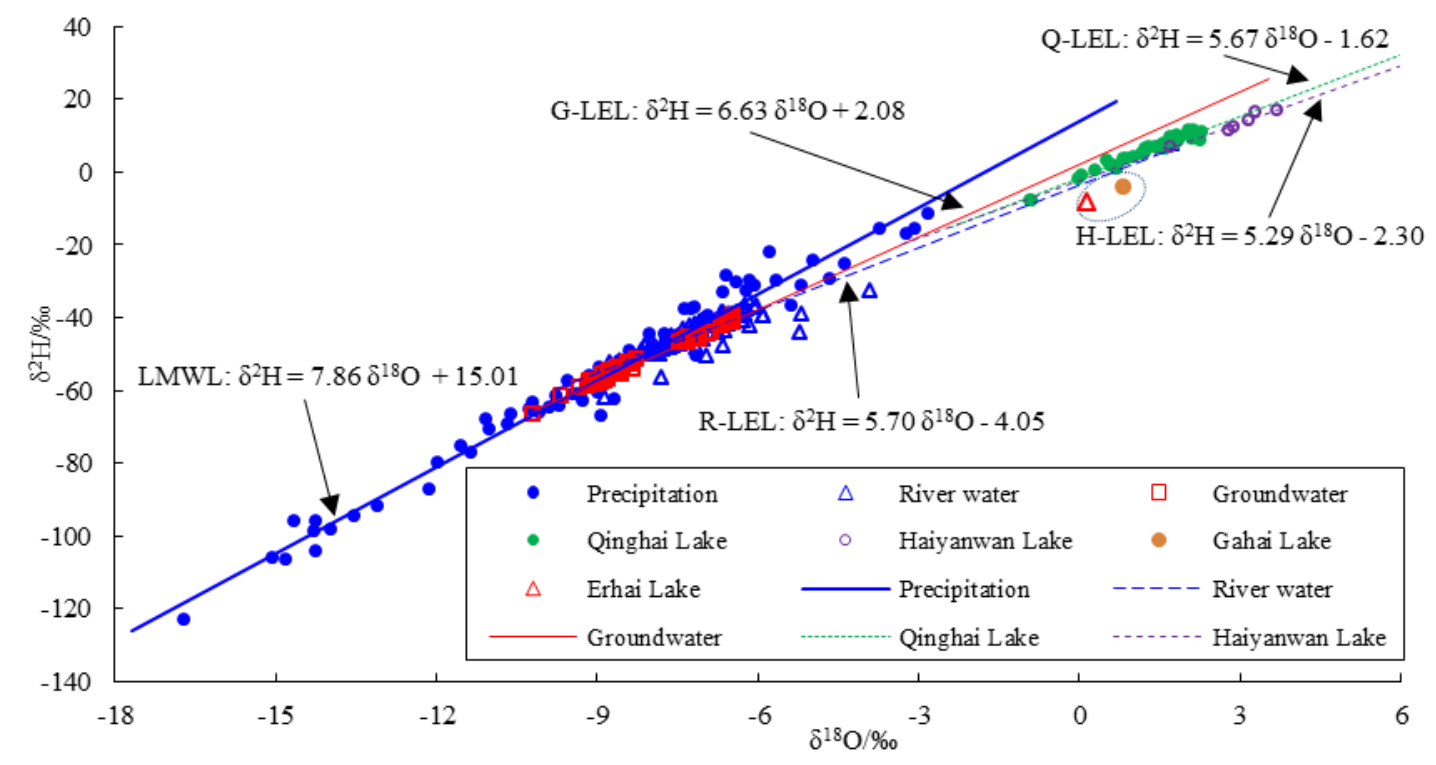




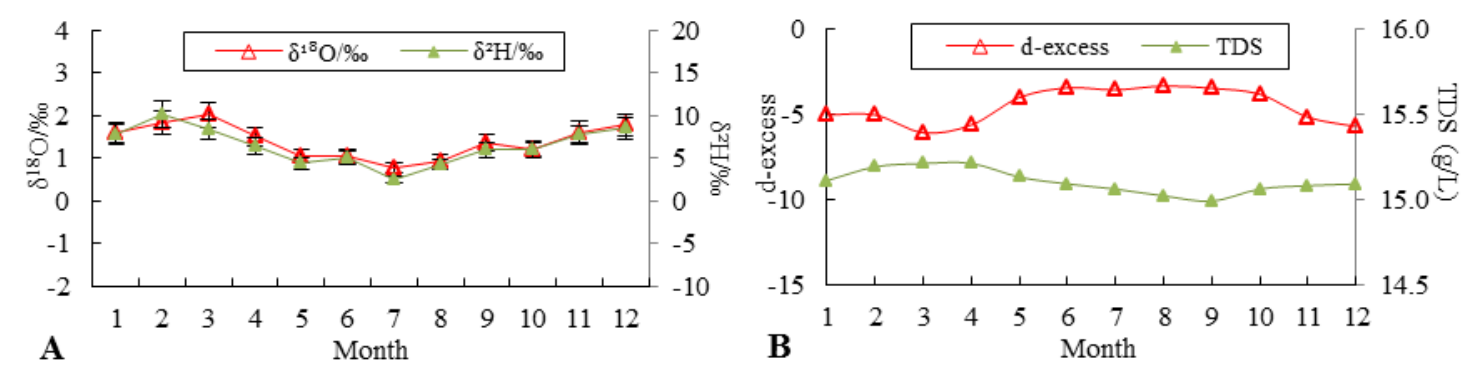

Fig. 3. 


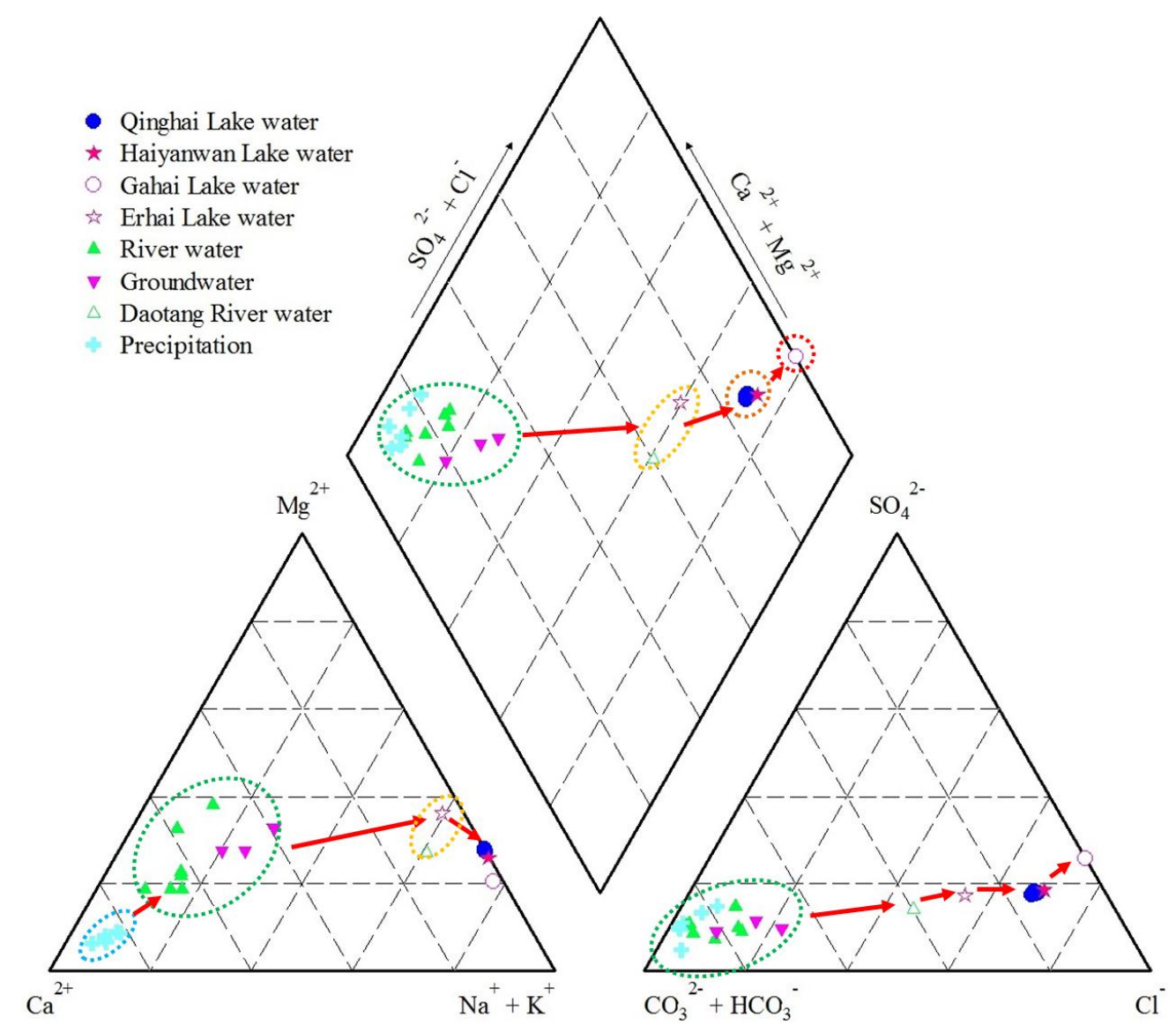

Fig. 4. 

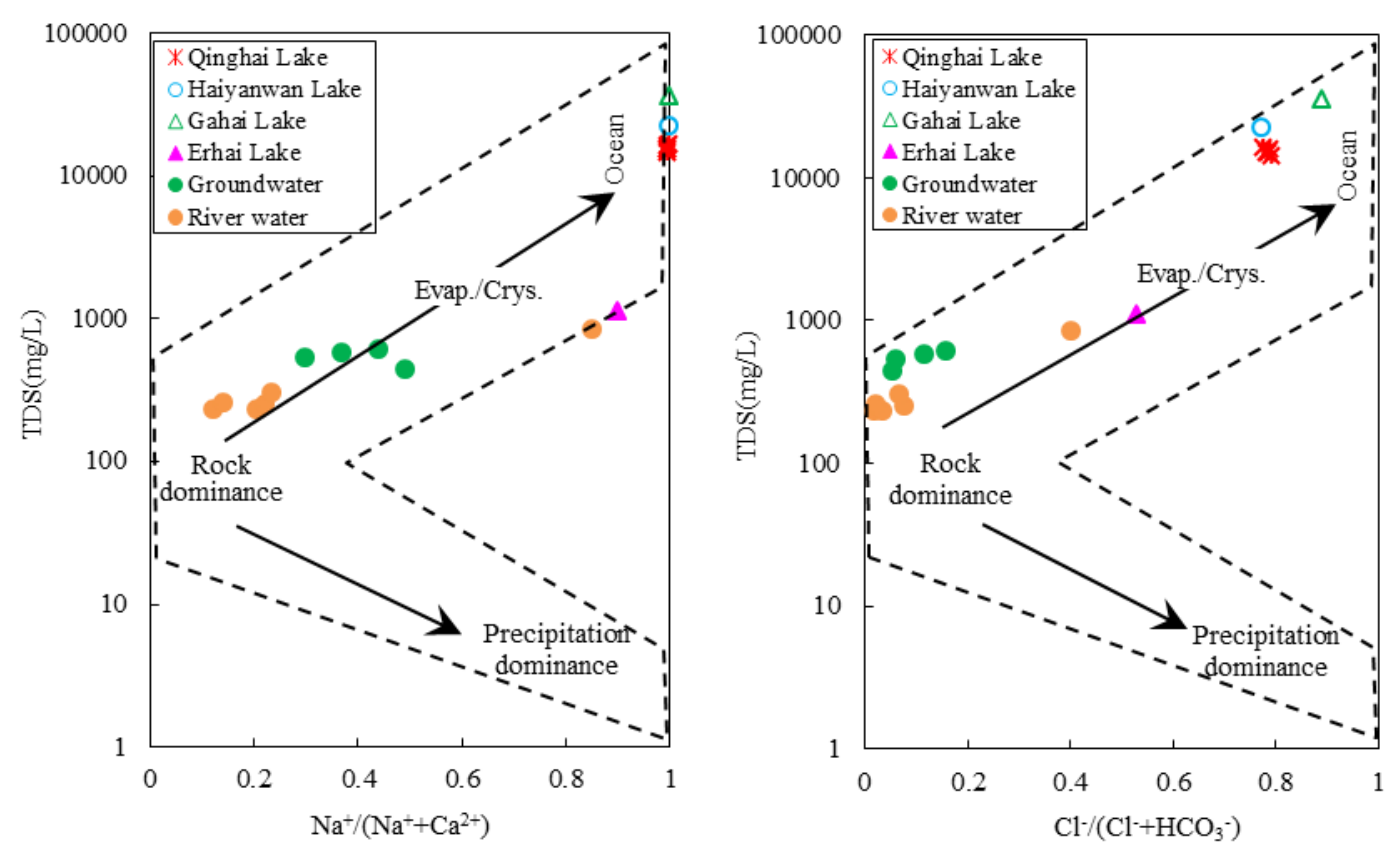

Fig. 5. 


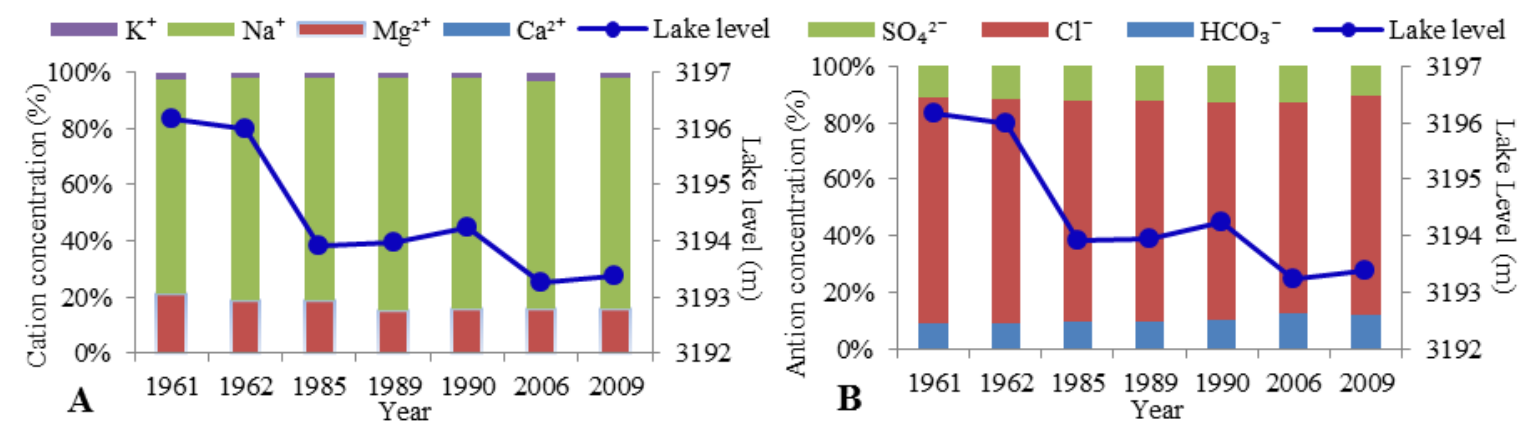

Fig. 6. 


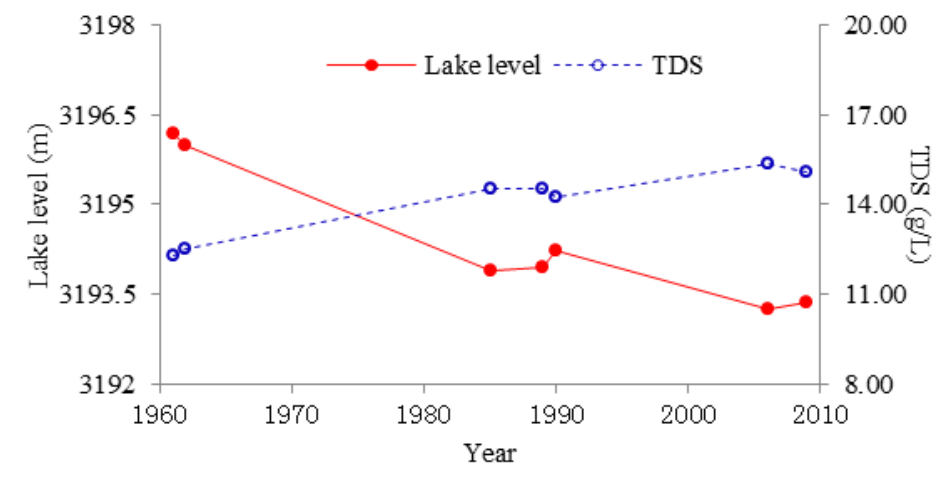

Fig. 7. 


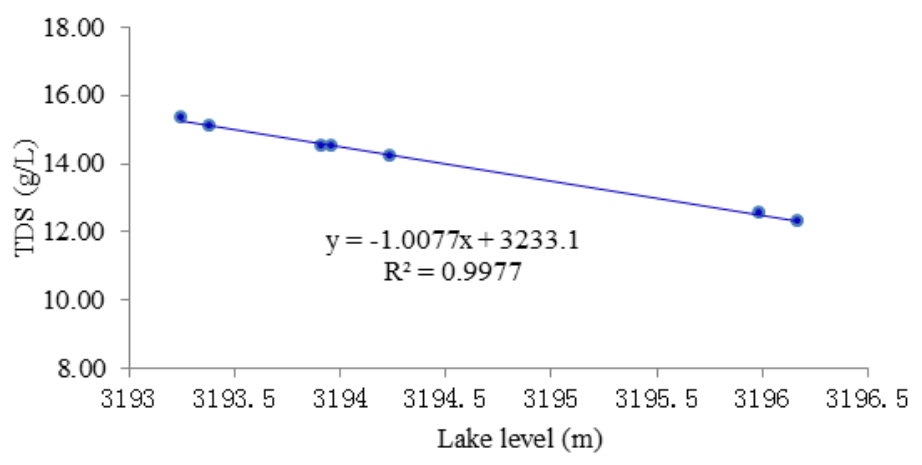

Fig. 8. 
Table 1. Stable isotopes and hydrochemical composition of lake water, river water, and groundwater in sampled water sources of Qinghai basin. Sample site locations given in Figure 1.

\begin{tabular}{|c|c|c|c|c|c|c|c|c|c|c|c|c|}
\hline $\begin{array}{l}\text { Sam } \\
\text { ple } \\
\text { sites }\end{array}$ & $\begin{array}{l}\text { Water } \\
\text { types }\end{array}$ & $\begin{array}{c}\delta^{18} \\
\mathrm{O} \\
(\%) \\
)\end{array}$ & $\begin{array}{l}\delta^{2} \mathrm{H} \\
(\% \mathrm{o})\end{array}$ & $\begin{array}{c}\mathrm{Ca}^{2+} \\
(\mathrm{mmol} / \\
\mathrm{L})\end{array}$ & $\begin{array}{c}\mathrm{Mg}^{2+} \\
(\mathrm{mmol} / \\
\mathrm{L})\end{array}$ & $\begin{array}{c}\mathrm{Na}^{+} \\
(\mathrm{mmol} / \\
\mathrm{L})\end{array}$ & $\begin{array}{c}\mathrm{K}^{+} \\
(\mathrm{mmol} / \\
\mathrm{L})\end{array}$ & $\begin{array}{c}\mathrm{HCO}_{3}^{-} \\
(\mathrm{mmol} / \\
\mathrm{L})\end{array}$ & $\begin{array}{c}\mathrm{Cl}^{-} \\
(\mathrm{mmol} / \\
\mathrm{L})\end{array}$ & $\begin{array}{c}\mathrm{SO}_{4}{ }^{2-} \\
(\mathrm{mmol} / \\
\mathrm{L})\end{array}$ & $\begin{array}{l}\text { TD } \\
\mathrm{S} \\
(\mathrm{g} / \\
\mathrm{L})\end{array}$ & $\begin{array}{c}\mathrm{EC} \\
(\mathrm{mS} / \mathrm{c} \\
\mathrm{m})\end{array}$ \\
\hline L1 & $\begin{array}{c}\text { Qinghai } \\
\text { Lake }\end{array}$ & $\begin{array}{c}1.9 \\
5\end{array}$ & 9.59 & 0.28 & 31.24 & 164.17 & 3.74 & 26.93 & 170.78 & 24.31 & $\begin{array}{l}14 . \\
72\end{array}$ & 15.7 \\
\hline L2 & $\begin{array}{c}\text { Qinghai } \\
\text { Lake }\end{array}$ & $\begin{array}{c}0.9 \\
0\end{array}$ & 3.69 & 0.36 & 30.40 & 159.78 & 3.46 & 25.26 & 167.04 & 22.82 & $\begin{array}{l}14 . \\
22\end{array}$ & 15.6 \\
\hline L3 & $\begin{array}{c}\text { Qinghai } \\
\text { Lake }\end{array}$ & $\begin{array}{c}1.6 \\
8\end{array}$ & 7.85 & 0.28 & 34.79 & 182.74 & 4.00 & 28.18 & 182.06 & 24.96 & $\begin{array}{l}15 . \\
78\end{array}$ & 16.9 \\
\hline L4 & $\begin{array}{c}\text { Qinghai } \\
\text { Lake }\end{array}$ & $\begin{array}{c}1.4 \\
6\end{array}$ & 6.75 & --- & 36.19 & 194.57 & 4.26 & 29.85 & 179.88 & 24.46 & $\begin{array}{l}16 . \\
06\end{array}$ & 18.1 \\
\hline L5 & $\begin{array}{c}\text { Qinghai } \\
\text { Lake }\end{array}$ & $\begin{array}{c}0.4 \\
3\end{array}$ & 0.25 & 0.29 & 32.00 & 169.26 & 3.69 & 27.33 & 170.56 & 23.17 & $\begin{array}{l}14 . \\
76\end{array}$ & 16.2 \\
\hline L6 & $\begin{array}{l}\text { Haiyanw } \\
\text { an Lake }\end{array}$ & $\begin{array}{c}2.9 \\
2\end{array}$ & $\begin{array}{c}13.1 \\
0\end{array}$ & 0.17 & 56.88 & 316.00 & 7.10 & 38.43 & 268.80 & 35.66 & $\begin{array}{l}24 . \\
23\end{array}$ & 25.1 \\
\hline L7 & $\begin{array}{l}\text { Gahai } \\
\text { Lake }\end{array}$ & $\begin{array}{c}0.8 \\
4\end{array}$ & $\begin{array}{c}-4.4 \\
0\end{array}$ & 0.48 & 51.71 & 403.03 & 12.05 & 29.52 & 379.00 & 65.69 & $\begin{array}{l}32 . \\
56\end{array}$ & 48.6 \\
\hline L8 & $\begin{array}{l}\text { Erhai } \\
\text { Lake }\end{array}$ & $\begin{array}{c}0.1 \\
4\end{array}$ & $\begin{array}{c}-8.1 \\
3\end{array}$ & 0.42 & 3.70 & 11.70 & 0.44 & 3.87 & 7.49 & 1.20 & $\begin{array}{c}1.0 \\
1\end{array}$ & 1.2 \\
\hline $\mathrm{R} 1$ & $\begin{array}{l}\text { Buha } \\
\text { River }\end{array}$ & $\begin{array}{l}-7 . \\
52\end{array}$ & $\begin{array}{c}-46 . \\
69\end{array}$ & 1.75 & 0.61 & 0.80 & 0.04 & 3.59 & 0.51 & 0.35 & $\begin{array}{c}0.3 \\
8\end{array}$ & 0.20 \\
\hline $\mathrm{R} 2$ & $\begin{array}{l}\text { Shaliu } \\
\text { River }\end{array}$ & $\begin{array}{l}-6 . \\
96\end{array}$ & $\begin{array}{c}-41 . \\
97\end{array}$ & 1.44 & 0.52 & 0.64 & 0.04 & 3.80 & 0.14 & 0.23 & $\begin{array}{c}0.3 \\
4\end{array}$ & 0.16 \\
\hline $\mathrm{R} 3$ & $\begin{array}{c}\text { Haergai } \\
\text { River }\end{array}$ & $\begin{array}{l}-7 \\
73\end{array}$ & $\begin{array}{c}-47 . \\
71\end{array}$ & 1.64 & 0.92 & 0.47 & 0.05 & 4.07 & 0.17 & 0.25 & $\begin{array}{c}0.3 \\
8\end{array}$ & 0.18 \\
\hline $\mathrm{R} 4$ & $\begin{array}{c}\text { Daotang } \\
\text { River }\end{array}$ & $\begin{array}{l}-3 . \\
90\end{array}$ & $\begin{array}{c}-32 \\
58\end{array}$ & 0.98 & 2.21 & 9.78 & 0.15 & 5.79 & 6.73 & 1.03 & $\begin{array}{c}1.0 \\
1\end{array}$ & 1.04 \\
\hline $\mathrm{R} 5$ & $\begin{array}{l}\text { Ganzi } \\
\text { River }\end{array}$ & $\begin{array}{l}-5 . \\
19\end{array}$ & $\begin{array}{c}-38 . \\
99\end{array}$ & 1.6 & 1.27 & 0.85 & 0.02 & 4.69 & 0.59 & 0.21 & $\begin{array}{c}0.4 \\
4\end{array}$ & 0.24 \\
\hline R6 & $\begin{array}{l}\text { Quanji } \\
\text { River }\end{array}$ & $\begin{array}{l}-6 . \\
35\end{array}$ & $\begin{array}{c}-38 \\
84\end{array}$ & 1.62 & 0.43 & 0.39 & 0.04 & 3.77 & 0.24 & 0.19 & $\begin{array}{c}0.3 \\
4\end{array}$ & 0.15 \\
\hline $\mathrm{R} 7$ & $\begin{array}{l}\text { Heima } \\
\text { River }\end{array}$ & $\begin{array}{l}-7 . \\
31\end{array}$ & $\begin{array}{c}-44 . \\
98\end{array}$ & 2.29 & 0.65 & 0.93 & 0.08 & 4.16 & 0.79 & 0.25 & $\begin{array}{c}0.4 \\
4\end{array}$ & 0.29 \\
\hline $\mathrm{R} 8$ & $\begin{array}{l}\text { Chaji } \\
\text { River }\end{array}$ & $\begin{array}{l}-7 . \\
79\end{array}$ & $\begin{array}{c}-48 . \\
57\end{array}$ & 2.18 & 0.65 & 1.08 & 0.07 & 4.26 & 0.76 & 0.27 & $\begin{array}{c}0.4 \\
4\end{array}$ & 0.29 \\
\hline G1 & $\begin{array}{c}\text { Groundw } \\
\text { ater }\end{array}$ & $\begin{array}{l}-6 . \\
54\end{array}$ & $\begin{array}{c}-41 . \\
28\end{array}$ & 2.11 & 1.24 & 2.15 & 0.07 & 5.43 & 1.23 & 0.43 & $\begin{array}{c}0.5 \\
9\end{array}$ & 0.42 \\
\hline G2 & $\begin{array}{c}\text { Groundw } \\
\text { ater }\end{array}$ & $\begin{array}{l}-8 . \\
66\end{array}$ & $\begin{array}{c}-54 . \\
91\end{array}$ & 3.7 & 4.46 & 20.17 & 0.23 & 12.02 & 10.99 & 3.42 & $\begin{array}{c}2.2 \\
6\end{array}$ & 2.38 \\
\hline G3 & $\begin{array}{c}\text { Groundw } \\
\text { ater }\end{array}$ & $\begin{array}{l}-8 . \\
61\end{array}$ & $\begin{array}{c}-53 . \\
57\end{array}$ & 1.88 & 1.58 & 2.58 & 0.12 & 5.49 & 1.79 & 0.39 & $\begin{array}{c}0.6 \\
2\end{array}$ & 0.46 \\
\hline
\end{tabular}




\begin{tabular}{|c|c|c|c|c|c|c|c|c|c|c|c|c|}
\hline G4 & $\begin{array}{c}\text { Groundw } \\
\text { ater }\end{array}$ & $\begin{array}{l}-9 . \\
08\end{array}$ & $\begin{array}{c}-58 . \\
09\end{array}$ & 1.27 & 0.65 & 2.13 & 0.06 & 4.70 & 0.48 & 0.15 & $\begin{array}{c}0.4 \\
4\end{array}$ & 0.22 \\
\hline G5 & $\begin{array}{c}\text { Groundw } \\
\text { ater }\end{array}$ & $\begin{array}{l}-7 . \\
32\end{array}$ & $\begin{array}{c}-45 . \\
99\end{array}$ & 2.03 & 1.09 & 1.51 & 0.07 & 5.41 & 0.62 & 0.31 & $\begin{array}{c}0.5 \\
3\end{array}$ & 0.33 \\
\hline
\end{tabular}


Table 2. Local meteoric water line (LMWL) and Evaporation lines (LEL) of river water, ground water, and lake water in the Qinghai Lake Basin.

\begin{tabular}{|c|c|c|c|c|c|c|}
\hline Water types & $\begin{array}{l}\text { Line } \\
\text { types }\end{array}$ & Equations & n & $\mathbf{R}$ & $\mathbf{P}$ & Source \\
\hline Precipitation in Qinghai Lake Basin & LMWL & $\delta^{2} \mathrm{H}=7.86 \delta^{18} \mathrm{O}+15.01$ & 124 & 0.993 & $\mathrm{P}<0.001$ & Cui \& Li, 2015b \\
\hline River water around Qinghai Lake & R-LEL & $\delta^{2} \mathrm{H}=5.70 \delta^{18} \mathrm{O}-4.05$ & 38 & 0.930 & $\mathrm{P}<0.001$ & Cui \& Li, 2015a \\
\hline Ground water around Qinghai Lake & G-LEL & $\delta^{2} \mathrm{H}=6.63 \delta^{18} \mathrm{O}+2.08$ & 60 & 0.990 & $\mathrm{P}<0.001$ & Cui \& Li, 2014 \\
\hline Lake water of Qinghai Lake & Q-LEL & $\delta^{2} \mathrm{H}=5.67 \delta^{18} \mathrm{O}-1.62$ & 60 & 0.989 & $\mathrm{P}<0.001$ & This study \\
\hline Lake water of Haiyanwan Lake & H-LEL & $\delta^{2} \mathrm{H}=5.29 \delta^{18} \mathrm{O}-2.30$ & 6 & 0.980 & $\mathrm{P}<0.001$ & This study \\
\hline
\end{tabular}


Table 3. Changes of hydrochemical composition of lake water in Qinghai Lake and surrounding lakes from 1961 to 2009.

\begin{tabular}{|c|c|c|c|c|c|c|c|c|c|c|c|}
\hline Lake & $\begin{array}{l}\text { Sampl } \\
\text { ing } \\
\text { time }\end{array}$ & $\begin{array}{c}\text { Lake le } \\
\text { vel } \\
\text { (m) }\end{array}$ & $\begin{array}{c}\mathrm{Ca}^{2+} \\
(\mathrm{mmol} \\
/ \mathrm{L})\end{array}$ & $\begin{array}{c}\mathrm{Mg}^{2+} \\
(\mathrm{mmol} \\
/ \mathrm{L})\end{array}$ & $\begin{array}{c}\mathrm{Na}^{+} \\
(\mathrm{mmol} \\
/ \mathrm{L})\end{array}$ & $\begin{array}{c}\mathrm{K}^{+} \\
(\mathrm{mmol} \\
/ \mathrm{L})\end{array}$ & $\begin{array}{c}\mathrm{HCO}_{3}{ }^{-} \\
(\mathrm{mmol} \\
/ \mathrm{L})\end{array}$ & $\begin{array}{c}\mathrm{Cl}^{-} \\
(\mathrm{mmol} \\
/ \mathrm{L})\end{array}$ & $\begin{array}{c}\mathrm{SO}_{4}^{2-} \\
(\mathrm{mmol} \\
/ \mathrm{L})\end{array}$ & $\begin{array}{c}\text { TD } \\
\mathrm{S} \\
(\mathrm{g} / \\
\mathrm{L})\end{array}$ & $\begin{array}{c}\text { Data sourc } \\
\mathrm{e}\end{array}$ \\
\hline $\begin{array}{l}\text { Qinghai } \\
\text { Lake }\end{array}$ & 1961 & 3196.17 & 0.24 & 36.17 & 133.70 & 3.62 & 17.15 & 146.90 & 20.36 & $\begin{array}{l}12 . \\
31\end{array}$ & $\begin{array}{c}\text { LIGCAS } \\
(1979)\end{array}$ \\
\hline $\begin{array}{l}\text { Qinghai } \\
\text { Lake }\end{array}$ & 1962 & 3195.99 & 0.22 & 33.71 & 142.91 & 3.59 & 16.85 & 144.11 & 20.98 & $\begin{array}{l}12 . \\
55\end{array}$ & $\begin{array}{c}\text { LIGCAS } \\
(1979)\end{array}$ \\
\hline $\begin{array}{l}\text { Qinghai } \\
\text { Lake }\end{array}$ & 1985 & 3193.91 & 0.32 & 40.80 & 172.57 & 4.03 & 19.68 & 155.90 & 24.77 & $\begin{array}{l}14 . \\
54\end{array}$ & $\begin{array}{c}\text { LZBCAS } \\
(1994)\end{array}$ \\
\hline $\begin{array}{l}\text { Qinghai } \\
\text { Lake }\end{array}$ & 1989 & 3193.96 & 0.33 & 32.57 & 177.65 & 3.64 & 18.99 & 155.70 & 24.35 & $\begin{array}{l}14 . \\
51\end{array}$ & $\begin{array}{c}\text { LZBCAS } \\
(1994)\end{array}$ \\
\hline $\begin{array}{l}\text { Qinghai } \\
\text { Lake }\end{array}$ & 1990 & 3194.24 & 0.25 & 32.92 & 170.87 & 4.10 & 19.67 & 146.58 & 24.48 & $\begin{array}{l}14 . \\
23\end{array}$ & $\begin{array}{c}\text { Sun et al. } \\
\text { (1995) }\end{array}$ \\
\hline $\begin{array}{l}\text { Qinghai } \\
\text { Lake }\end{array}$ & 2006 & 3193.25 & 0.27 & 32.27 & 176.65 & 5.80 & 23.50 & 179.24 & 26.06 & $\begin{array}{l}15 . \\
37\end{array}$ & $\begin{array}{l}\text { Jin et al. } \\
\text { (2010) }\end{array}$ \\
\hline $\begin{array}{l}\text { Qinghai } \\
\text { Lake }\end{array}$ & 2009 & 3193.38 & 0.30 & 32.92 & 174.10 & 3.83 & 27.51 & 174.06 & 23.94 & $\begin{array}{l}15 . \\
11\end{array}$ & This study \\
\hline $\begin{array}{l}\text { Gahai } \\
\text { Lake }\end{array}$ & 1961 & --- & 0.30 & 58.38 & 300.09 & 7.95 & 18.51 & 251.62 & 46.80 & $\begin{array}{l}24 . \\
94\end{array}$ & $\begin{array}{c}\text { LIGCAS } \\
(1979)\end{array}$ \\
\hline $\begin{array}{l}\text { Gahai } \\
\text { Lake }\end{array}$ & 1962 & --- & 0.40 & 66.21 & 365.78 & 9.31 & 18.43 & 251.08 & 53.71 & $\begin{array}{c}27 . \\
58\end{array}$ & $\begin{array}{c}\text { LIGCAS } \\
\text { (1979) }\end{array}$ \\
\hline $\begin{array}{l}\text { Gahai } \\
\text { Lake }\end{array}$ & 1989 & --- & 0.27 & 57.67 & 421.01 & 11.55 & 20.26 & 307.62 & 64.44 & $\begin{array}{l}31 . \\
94\end{array}$ & $\begin{array}{c}\text { LZBCAS } \\
\text { (1994) }\end{array}$ \\
\hline $\begin{array}{l}\text { Gahai } \\
\text { Lake }\end{array}$ & 1990 & --- & 0.25 & 56.25 & 411.30 & 11.28 & 19.84 & 293.85 & 62.92 & $\begin{array}{l}31 . \\
88\end{array}$ & $\begin{array}{c}\text { Sun et al. } \\
\text { (1995) }\end{array}$ \\
\hline $\begin{array}{l}\text { Gahai } \\
\text { Lake }\end{array}$ & 2006 & --- & 0.47 & 57.38 & 427.8 & 17.35 & 22.75 & 399.68 & 70.83 & $\begin{array}{l}34 . \\
29\end{array}$ & $\begin{array}{l}\text { Jin et al. } \\
\text { (2010) }\end{array}$ \\
\hline $\begin{array}{l}\text { Gahai } \\
\text { Lake }\end{array}$ & 2009 & --- & 0.48 & 51.71 & 403.03 & 12.05 & 29.52 & 379.02 & 65.69 & $\begin{array}{c}32 . \\
56\end{array}$ & This study \\
\hline $\begin{array}{c}\text { Haiyan } \\
\text { wan } \\
\text { Lake }\end{array}$ & 1989 & --- & 0.25 & 40.83 & 221.67 & 5.12 & 19.18 & 155.52 & 30.82 & $\begin{array}{l}17 . \\
96\end{array}$ & $\begin{array}{c}\text { LZBCAS } \\
(1994)\end{array}$ \\
\hline $\begin{array}{c}\text { Haiyan } \\
\text { wan } \\
\text { Lake }\end{array}$ & 1990 & --- & 0.25 & 40.42 & 218.26 & 5.13 & 21.15 & 149.90 & 30.31 & $\begin{array}{l}17 . \\
82\end{array}$ & $\begin{array}{c}\text { Sun et al. } \\
\text { (1995) }\end{array}$ \\
\hline $\begin{array}{c}\text { Haiyan } \\
\text { wan } \\
\text { Lake }\end{array}$ & 2009 & --- & 0.17 & 56.88 & 316.00 & 7.10 & 38.43 & 268.80 & 35.66 & $\begin{array}{l}24 . \\
23\end{array}$ & This study \\
\hline $\begin{array}{l}\text { Erhai } \\
\text { Lake }\end{array}$ & 1961 & --- & 0.29 & 3.60 & 11.65 & 0.49 & 4.30 & 5.66 & 2.17 & $\begin{array}{c}1.1 \\
5\end{array}$ & $\begin{array}{c}\text { LIGCAS } \\
\text { (1979) }\end{array}$ \\
\hline Erhai & 1989 & --- & 0.19 & 4.11 & 12.37 & 0.38 & 4.69 & 6.50 & 1.91 & 1.2 & LZBCAS \\
\hline
\end{tabular}




$\begin{array}{lcccccccccccc}\text { Lake } & & & & & & & & & & & & (1994) \\ \text { Erhai } & 2006 & --- & 0.38 & 4.34 & 13.89 & 0.60 & 9.10 & 9.73 & 1.90 & 1.5 & \text { Jin et al. } \\ \text { Lake } & & & & & & & & & & (2010) \\ \text { Erhai } & 2009 & --- & 0.42 & 3.70 & 11.70 & 0.44 & 3.87 & 7.49 & 1.20 & 1.0 & \text { This study } \\ \text { Lake } & & & & & & & & & & 1\end{array}$

